\title{
Football Memorabilia, Tattoos, and the Fall of Jim Tressel at The Ohio State
}

Jamel K. Donnor

William \& Mary, jkdonnor@wm.edu

Collin D. William Jr.

Follow this and additional works at: https://scholarworks.wm.edu/educationbookchapters

Part of the Higher Education Commons, and the Sports Studies Commons

\section{Recommended Citation}

Donnor, Jamel K. and William, Collin D. Jr., "Football Memorabilia, Tattoos, and the Fall of Jim Tressel at The Ohio State" (2017). School of Education Book Chapters. 19.

https://scholarworks.wm.edu/educationbookchapters/19

This Book Chapter is brought to you for free and open access by the School of Education at W\&M ScholarWorks. It has been accepted for inclusion in School of Education Book Chapters by an authorized administrator of W\&M ScholarWorks. For more information, please contact scholarworks@wm.edu. 

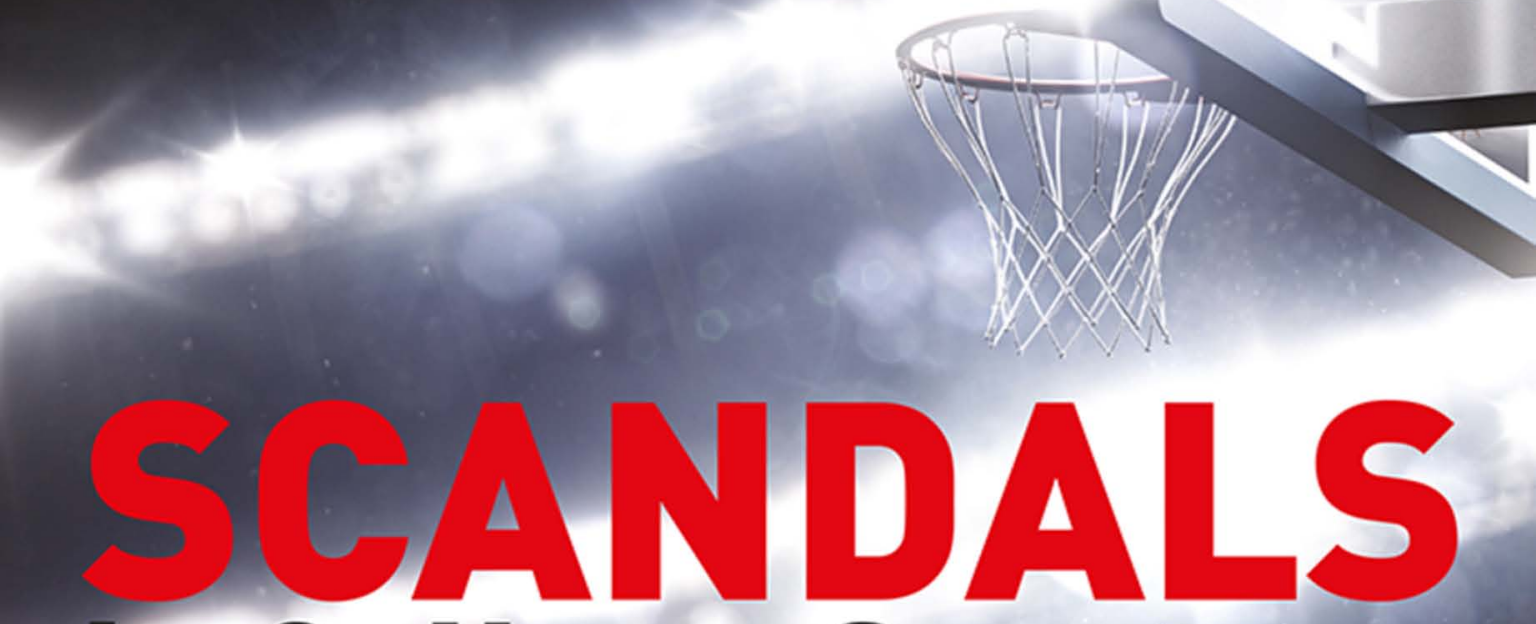

in College Sports

Q

Edited by

SHAUN R. HARPER and

JAMEL K. DONNOR

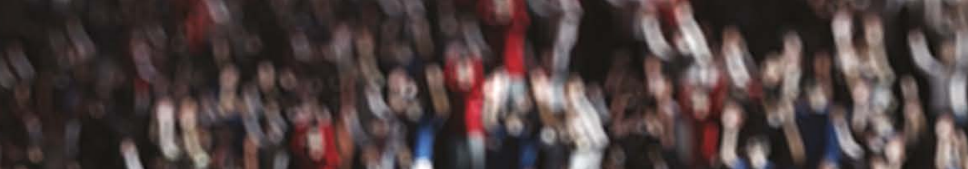
iny 4 if fill

deripes

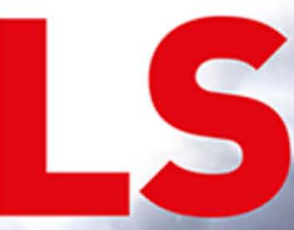




\section{SCANDALS IN COLLEGE SPORTS}

Edited by Shaun R. Harper and Jamel K. Donnor 
First published 2017

by Routledge

711 Third Avenue, New York, NY 10017

and by Routledge

2 Park Square, Milton Park, Abingdon, Oxon OX14 4RN

Routledge is an imprint of the Taylor E Francis Group, an informa business

(C) 2017 Taylor \& Francis

The right of Shaun R. Harper and Jamel K. Donnor, and of the authors for their individual chapters, to be identified as the authors of this part of the Work has been asserted by them in accordance with sections 77 and 78 of the Copyright, Designs and Patents Act 1988.

All rights reserved. No part of this book may be reprinted or reproduced or utilised in any form or by any electronic, mechanical, or other means, now known or hereafter invented, including photocopying and recording, or in any information storage or retrieval system, without permission in writing from the publishers.

Trademark notice: Product or corporate names may be trademarks or registered trademarks, and are used only for identification and explanation without intent to infringe.

British Library Cataloguing in Publication Data

A catalogue record for this book is available from the British Library

Library of Congress Cataloging in Publication Data

Names: Harper, Shaun R., 1975- author. | Donnor, Jamel K., author.

Title: Scandals in College Sports / By Shaun R. Harper and Jamel K. Donnor. Description: New York, NY London : Routledge, 2017. | Includes index. Identifiers: LCCN 2016039051 | ISBN 9781138830547 (hardback) | ISBN 9781138830554 (pbk.) | ISBN 9781315737225 (ebook) |

ISBN 9781317569404 (mobi/kindle)

Subjects: LCSH: College sports--Corrupt practices-United States--History. | College sports--Moral and ethical aspects--United States. | College athletes-United States--Conduct of life. | National Collegiate Athletic Association-Rules and practice.

Classification: LCC GV351 .H37 2017 | DDC 796.04/3--dc23

LC record available at https://lccn.loc.gov/2016039051

ISBN: 978-1-138-83054-7 (hbk)

ISBN: 978-1-138-83055-4 (pbk)

ISBN: 978-1-315-73722-5 (ebk)

Typeset in Bembo

by Taylor \& Francis Books 


\section{CONTENTS}

Preface $x$

Chapter Structure and Section Overviews xii

Acknowledgments xiv

1 Bad Sportsmanship: Why College Sports Are so Scandalous 1 Shaun R. Harper and Jamel K. Donnor

\section{FIRST QUARTER}

\section{Recruitment and Compensation Scandals}

2 Till Death Do Us Part: The Rise and Fall of Mustang Mania at Southern Methodist University

David Horton Jr. and Justin L. Davis

3 Nevin Shapiro's $\$ 930$ Million Ponzi Scheme at the University of Miami

C. Keith Harrison and Scott Bukstein

4 University of Alabama Albert Means College Recruiting Scandal

Louis Harrison Jr., Albert Y. Bimper Jr., Langston Clark, and Martin Smith

5 Sports Agents and the Recruitment of Reggie Bush to the University of Southern California

Timothy Davis and Kenneth L. Shropshire 
6 Football Memorabilia, Tattoos, and the Fall of Jim Tressel at Ohio State Jamel K. Donnor and Collin D. Williams Jr.

7 Suspect Recruiting: The SUNY Binghamton Basketball Scandal Collin D. Williams Jr.

8 Covering Up Murder: The Death of Patrick Dennehy at Baylor University

Karen Weaver

\section{SECOND QUARTER}

\section{Competition Schemes, Academics, and Unfair Advantages}

9 University of Toledo Point-Shaving Scandal

Eddie Comeaux and Mercedes Rosado

10 Academic Misconduct at Florida State University

Joy Gaston Gayles and Christopher Faison

11 Fake "Paper Classes" at UNC Chapel Hill

Timothy Zimmer and Shaun R. Harper

12 The NCAA on Drugs: Players, Performance-Enhancing Drugs, and the Need for Tougher Testing Policies and Practices

Ross D. Aikins, Marc E. Christian, and Shaun R. Harper

\section{THIRD QUARTER}

\section{Abuse and Harm to Student-Athletes}

13 The Bobby Knight Player-Abuse Scandals at Indiana University James Soto Antony, Jennifer Lee Hoffman, and Jacob Houston

14 Praying to Play: A Coach's Control of Players' Spiritual Lives at Oakland University

Demetri L. Morgan, Horatio W. Blackman, and Shaun R. Harper

15 No Drinking, No Drugs, No Lesbians: Coach Rene Portland and the Culture of Homophobia in Women's Basketball at Penn State

Edward J. Smith

16 Hazing on Women's Sport Teams at Three Colleges and Universities 
17 "Numerous and Repeated Concussions" at Eastern Illinois University: Adrian Arrington's Lawsuit Against the NCAA Whitney N. Griffin

\section{FOURTH QUARTER}

\section{Sexual Misconduct and Gender Discrimination}

18 Wrestlers Gone Wild: Gay Porn Starring University of Nebraska Student-Athletes

Shaun R. Harper and Charles H.F. Davis III

19 Illegal Contact? Player-Coach Sexual Relationships at LSU and Boston College

Willis A. Jones and Neal H. Hutchens

20 Protecting the Pride: The Penn State Jerry Sandusky Child Sex-Abuse Scandal

Andrew Howard Nichols and Emil L. Cunningham

21 Sex Discrimination and Abuse of a Female Kicker on the University of Colorado Football Team

Frank Harris III

22 Gender Discrimination and Retaliation Under Title IX at Fresno State

Jennifer Lee Hoffman, Jacqueline McDowell, and Valyncia C. Raphael 


\section{6}

\section{FOOTBALL MEMORABILIA,}

TATTOOS, AND THE FALL OF JIM TRESSEL AT OHIO STATE

Jamel K. Donnor and Collin D. Williams Jr.

Colloquially referred to as the "senator" because of his calculated responses to the media and trademark sweater vests, Jim Tressel, the former head football coach for The Ohio State University (OSU), tendered his resignation on May 30, 2011, citing that the "recent situation has been a distraction for our great university" (Tressel, 2011, p. 1). The "recent situation" Tressel was referring to was a story posted on Yahoo!Sports, an online sports newspaper, which stated that for approximately eight months he (Tressel) had failed to inform the university's athletics compliance department that five members of the football team, including starting quarterback Terrelle Pryor, had sold or exchanged OSU sports memorabilia for tattoos to Mr. Edward Rife, the owner of Fine Line Ink Tattoo, a tattoo parlor in Columbus, Ohio. A violation of the NCAA's amateurism policy regarding extra benefits and preferential treatment, Tressel - the most successful coach at Ohio State since Woody Hayes - knew that reporting the student-athletes' infractions would result in their immediate disqualification, and for all intents and purposes preclude the team from contending in a Bowl Championship Series (BCS) postseason bowl game.

Perhaps what was most troubling about the situation was Tressel's behavior upon learning of the violations and his actions once the matter became public. For example, upon initial notification of the student-athletes' infractions by Christopher Cicero, a local attorney and former football player at Ohio State, Tressel stated to Cicero by email that he would "investigate the matter and take appropriate action" (Robinson \& Wetzel, 2011, p. 2). While there is very little information to determine whether Tressel conducted an investigation as stated, it was clear, according to Tressel's Ohio State email account, that he chose to handle the matter personally rather than notify the university's compliance department, athletic director (Gene Smith), or president (E. Gordon Gee), as stipulated in his employment contract. Similarly, once the university began an internal investigation into the situation, 
Tressel falsely attested that he had reported any knowledge of NCAA violations to the university.

Tressel's conduct is symptomatic of the commercial forces and competitive pressures to win in major college football (Oriard, 2009; Clotfelter, 2011). For example, despite being a nonprofit organization, the NCAA (2010) reported that its total revenue generated from big-time college football alone was $\$ 14,841,000$; a $\$ 5,632,000$ increase from $\$ 9,209,000$ reported in 2004 (NCAA, 2010, p. 27). Similarly, universities with high-profile teams, such as Ohio State, generate millions of dollars in revenue through ticket and merchandise sales, corporate sponsors, and television contracts. Likewise, the compensation packages for head (and assistant coaches) at many of the top football programs currently exceed $\$ 1$ million (Upton, Gillum, \& Berkowitz, 2010). Consider, for example, that Tressel's contract at the time of his resignation was worth approximately $\$ 17.4$ million over seven years. In addition to a base salary of $\$ 550,000$, a "longevity bonus" of $\$ 450,000$, and the use of a private jet for recruiting visits, Tressel's contract stipulated that he receive a $\$ 25,000$ raise per year, and an annual contribution of $\$ 40,000$ toward his retirement from the university (Upton et al., 2010). In essence, the money in major college football is exorbitant.

The goal of this chapter is threefold. The first is to describe the situation that involved Tressel and OSU's football program in-depth. The second goal is to situate the Tressel scandal (and major college football) within a larger sociocultural and political economic context. Specifically, by explaining what the former head coach's and the student-athletes' actions convey regarding the commercialization of intercollegiate football, power, and wrongful benefice. The final goal is to provide an alternative ending to the OSU scandal - a counter-narrative, if you will. In particular, we consider whether Tressel would have had to resign if his studentathletes had been paid to play.

\section{The Case}

On April 2, 2010, former Ohio State head football coach Jim Tressel received the first of a string of emails from Christopher Cicero, a local attorney, indicating that several members of the OSU football team had received preferential treatment at a Columbus tattoo parlor as a result of selling their athletics trophies, awards, apparel, and equipment to Mr. Edward Rife, the owner of the parlor, who was also a convicted felon. According to Cicero's email, the U.S. Department of Justice (DOJ) raided Rife's home related to drug trafficking. In addition, Cicero indicated to Tressel that the student-athletes should "stay away from this guy [Rife] . . quite frankly for their safety" (NCAA, 2011a, pp. 6-7). In response, Tressel thanked Cicero and remarked that he would "get on it ASAP" (NCAA, 2011a, p. 7). According to the NCAA's (2011a) infractions report, rather than notify campus officials of Cicero's email, Tressel forwarded the email to Terrelle Pryor's mentor in Jeannette, Pennsylvania, to apprise him of the "situation."

In a subsequent email sent on April 16, 2010, Cicero informed Tressel that Rife confirmed his interactions with some of the current members of the football team, 
and Cicero asked that the email "be treated as confidential" (NCAA, 2011a, p. 7). In addition to thanking Cicero, Tressel said, "Keep me posted as to what I need to do if anything. I will keep pounding these kids hoping they grow up" (NCAA, 2011a, p. 7). The next correspondence between Tressel and Cicero occurred on April 19, 2010, when Tressel sent an email to Cicero stating that "I told [the student-athletes] to steer clear . . . is there any way I can get all the ring names. . . . . I have a little plan once this year's rings arrive" (NCAA, 2011a, p. 8). The "ring names" Tressel was referring to were the names of the student-athletes other than Terrelle Pryor and DeVier Posey who had sold their Big Ten Conference championship rings to Rife. The next day (April 20, 2010), Cicero replied to Tressel that he would contact the Columbus district attorney to inquire about the names of additional student-athletes who might have sold their conference rings to Rife (NCAA, 2011a). For nearly three weeks, Tressel did not notify university officials of the infractions or forward Cicero's emails to any university officials. In fact, the next correspondence between Tressel and Cicero did not occur until June 10, 2010, when Tressel sent an email inquiring about the additional ring names to which Cicero replied "no more names" (NCAA, 2011a, p. 8). For more than two months, Tressel failed to inform the university's compliance department, athletic director, or president of the violations.

Incidentally, Tressel and Cicero did not have additional communication until December 2010 - the same time at which OSU's Office of Legal Affairs received a letter from the DOJ informing Ohio State of the DOJ's criminal investigation of Rife, during which DOJ officials seized "a significant amount of OSU sports memorabilia" (U.S. Department of Justice [U.S. DOJ], 2010, p. 1). According to the U.S. Department of Justice (2010), while "many of the items seized were acquired from Ebay and autographed at various signing events . . several of the items seized appear to have belonged to Ohio State football players and/or The Ohio State University at some point in time" (p.1). Among the items seized were several Big Ten Conference Championship rings, trophies, and Ohio State football uniforms (U.S. DOJ, 2010). In response, Ohio State conducted an investigation of the violations, during which the student-athletes named in the DOJ's letter admitted to wrongdoing. From this investigation, the university uncovered additional violations (NCAA, 2011a, p. 4).

Among the additional violations uncovered from the internal institutional investigation were "payment to several student-athletes for work not performed at a private company, improper sale or exchange of institutional equipment or apparel for cash, or reduced-cost/free tattoos from Mr. Rife's tattoo parlor" (Ohio State Athletics, 2012, p. 1). According to the infractions report, between spring 2009 and summer 2011, Rife, without the university's knowledge or approval, arranged for the five football student-athletes to receive compensation for "work not performed" (Ohio State Athletics, 2012, p. 1).

\section{Sociocultural Context}

A major policy dilemma surrounding the Tressel scandal is the NCAA's amateurism policy, which, among other things, prohibits student-athletes from receiving 
compensation for their involvement in college athletics. According to the NCAA (2010), "student-athlete participation in intercollegiate athletics is an avocation" (NCAA Bylaw, Article 2.9). What this means is that a student who participates in NCAA-sanctioned athletic activities does so solely for its intrinsic value and functional purpose, such as learning the value of hard work and working within a team setting. Indeed, the sheer volume of "pay-for-play" infractions involving former elite student-athletes and institutions, such as Reggie Bush, Cam Newton, and the University of Miami, suggests that college athletes should be allowed to profit from their labors. Further, not only have critics of major college sports considered these bylaws unnecessary and exploitive (Glicksman, 2012; Wilbon, 2011; Sack, 2009), some have even likened them to apartheid (McCormick \& McCormick, 2010) and slavery (Rhoden, 2007). Though he cautions against slavery comparisons, leading civil rights historian Taylor Branch (2011) argues that the current college sports regime is more analogous to colonialism as "two of the noble principles on which the NCAA justifies its existence - 'amateurism' and the 'student-athlete' - are cynical hoaxes, legalistic confections propagated by the universities so they can exploit the skills and fame of young athletes" (Branch, 2011, p. 3). In The Shame of College Sports (2011), Branch states that "the real scandal is not that students are getting illegally paid or recruited" (p. 3). This section provides further insight into the controversy surrounding amateurism, more closely examining the rules, the context in which they were created, the racial dynamics in college football and basketball, and the extent to which various stakeholders profit from intercollegiate athletics.

\section{The Rules}

Article 2 of the NCAA manual for Division 1 athletics lists 16 Principles for Conduct of Intercollegiate Athletics. The Principle of Amateurism, or Bylaw Article 2.9, states:

Student-athletes shall be amateurs in an intercollegiate sport, and their participation should be motivated primarily by education and by the physical, mental and social benefits to be derived. Student participation in intercollegiate athletics is an avocation, and student-athletes should be protected from exploitation by professional and commercial enterprises.

(NCAA,2011b, p. 4)

Thus, the NCAA forbids students-athletes from receiving compensation for participation in college athletics beyond the cost of attending college. Under Article 15, the NCAA requires that an institution "shall not award financial aid to a student-athlete that exceeds the cost of attendance that normally is incurred by students enrolled in a comparable program at the institution" (NCAA, 2011b, p. 192) and "is an amount calculated by an institutional financial aid office" (NCAA, 2011b, p. 192). The bylaw violated by the OSU football players was 15.01.3: "Any student 
who receives financial aid other than that administered by the student-athlete's institution shall not be eligible for intercollegiate athletics competition" (NCAA, 2011 b, p. 191). By receiving money and tattoos in exchange for autographs, jerseys, and other athletic memorabilia, the OSU football players terminated their amateur status as student-athletes and became ineligible to compete.

\section{So-Called Student-Athletes}

The term "student-athlete" endorses the wholesome virtue of amateurism in college sports as well as the idealistic notion of academics over athletics. In reality, though, the phrase was created to protect the NCAA from adequately compensating its athletes by focusing on their status as students and preventing them from being identified as employees. When Ray Dennison died of a head injury in Colorado in the 1950s while playing football in Colorado for the Fort Lewis A\&M Aggies, his wife filed for workers'-compensation death benefits. According to the then-president of the NCAA, Walter Byers, "the threat was the dreaded notion that athletes could be identified as employees by state industrial commissions and the courts" (Byers and Hammer, 1997, p. 69). Thus, in a rapid, yet calculated, response, the NCAA "crafted the term student-athlete, and soon it was embedded in all NCAA rules and interpretations as a mandated substitute for words as players and athletes" (Byers and Hammer, 1997, p. 69). In conjunction with the amateurism rules, the term student-athlete preserves the image of college athletes as being students first, athletes second, but never employees. Since its creation, the NCAA and its member institutions have won several liability cases, successfully circumventing potentially large payouts. Evidently, the ambiguous term has been an exclusive shield for the NCAA, both promoting the falsified noble ideals of amateurism and serving as an effective legal defense (Branch, 2011). In State Compensation Insurance Fund $v$. Industrial Commission (1957), the Colorado Supreme Court ruled that neither Dennison nor his wife was eligible for benefits since the college was "not in the football business."

\section{Profits}

It is no longer feasible to deny that college sports has evolved into big business (Berkowitz \& Upton, 2011a, 2011b; Greenberg \& Smith, 2007; Upton, Gillum, \& Berkowitz, 2010; Wilson, Schrager, Burke, Hawkins \& Gauntt, 2011). The growing popularity of the major revenue-generating sports of basketball and football has been evidenced by enormous price tags on television rights packages, athletic department spending, and coaching salaries. In 2008, ESPN contracted to pay the NCAA $\$ 500$ million to broadcast four of the five major BCS games (Wilbon, 2011). Just the appearance of a team in a single BCS football game earned its respective conference $\$ 18$ million as well as an extra $\$ 4.5$ million for each team beyond the first (Bakalar, 2009). By 2011, four individual conferences - the Big 12, Pac 12, SEC, and ACC - had all signed football TV deals valued at more than a 
billion dollars each (Thamel, 2011). In 2010, the NCAA entered into a 14-year, $\$ 10.8$ billion dollar agreement with Turner/CBS sports to broadcast the Division I Men's Basketball Championship (Sandomir \& Thamel, 2010). In a study of athletic departments' total expenditures, Berkowitz and Upton (2011b) found that 228 athletic departments had spent a total of $\$ 6.8$ billion in 2010 . In the same year, the University of Alabama Athletics Department alone brought in \$26.6 million in revenue.

Coaches, too, have seen much of this profit. Other high-profile basketball and football coaches such as Rick Pitino, Nick Saban, and John Calipari eclipse even the $\$ 3.5$ million that Tressel made in 2011 - in the same year, each brought in $\$ 7.5, \$ 5.9$, and \$3.8 million, respectively (Berkowitz \& Upton, 2011a; Wilbon, 2011). In 2011, the coaches of approximately half of the 68 teams that made it to the 2011 NCAA Men's Basketball Tournament and 58 of the 120 FBS football schools earned salaries greater than $\$ 1$ million dollars (O’Neil, 2011). In contrast, players see menial amounts of this revenue. In fact, a joint study conducted by the National College Players Association (NCPA) and the Drexel University Department of Sport Management found that the average student-athlete at an FBS school on full scholarship has total earnings below the federal poverty line (Huma \& Staurowsky, 2011). The comparisons to apartheid, colonialism, and slavery become clearer by understanding the racial disparities between teams and coaches.

\section{Race}

When intercollegiate athletics were racially segregated and minority students were barred from participation, college teams, regardless of the sport, were exclusively White. Since their integration, though, the racial composition of college basketball and football teams has grown to become overwhelmingly Black, while the racial composition of the managers of the sports (coaches, athletic directors, university officials, NCAA or conference officials, and so on) has remained overwhelmingly White (McCormick \& McCormick, 2010, 2012). In 2010, for example, the top 25 basketball and football teams were 66 and 61 percent Black, respectively, while the administrators for those same teams were 91 and 96 percent White, respectively (McCormick \& McCormick, 2012). While it is blatant that Black men are the majority in these sports and that their talent and labor have generated income for their schools, the revenue has been disproportionately distributed. What is interesting, though, is that the amateurism laws that the NCAA put in place apply solely to the athletes. As McCormick and McCormick (2012) explain, "amateurism reserves the vast financial rewards for the managers of college sports who are almost exclusively of European descent" (p. 18).

\section{Alternate Ending}

In late 2011, after being rocked by a bevy of scandals, the NCAA convened with conference representatives, member institution officials, and a variety of sports 
personalities who had demonstrated an acute interest in the compensation of college athletes to amend their amateurism rules. By the close of the weekend-long conference, the NCAA had agreed, in principle, "to amend Article 12 on amateurism, Article 15 on financial aid, and Article 16 on awards, benefits, and expenses" and "allow student-athletes the opportunity to open additional streams of income by signing endorsement agreements and selling items associated with their athletic achievements without losing their eligibility to compete" (Glicksman, 2012, p. 7). Long-time proponents of the free-market view of college sports, ESPN columnist and tenured sports journalist Michael Wilbon, and Allen Sack, a professor at the College of Business at the University of New Haven and member of the 1966 University of Notre Dame national championship football team, were voted the most valuable players (MVPs) for presenting compelling arguments in favor of paying student-athletes. The passage below summarizes the free-market view as explained by Sack (2009):

No good reason exists for preventing athletes from engaging in the same entrepreneurial activities as their celebrity coaches. Big-time college athletes should be able to endorse products, get paid for speaking engagements and be compensated for the use of their likenesses on licensed products. They should be allowed to negotiate an actual contract with the N.B.A. as part of a final project in a finance class, and have an agent. These athletes are working their way through college by playing professional college sports. It is time to accept this reality and move on.

In addressing the audience, Wilbon (2011) confessed, "he used to argue vehemently against paying college athletes," believing "tuition, room, board and books were compensation enough." However, after the NCAA began receiving " $\$ 11$ billion dollars for three weekends of television per year," he admittedly became interested not in "distributing the funds equitably or even paying every college athlete," but rather "in seeing the people who produce the revenue share a teeny, tiny slice of it." His stance is based in capitalism where "not everything is equal" or "fair." For example, "the most distinguished professor at the University of Alabama won't make $\$ 5.9$ million in his entire tenure in Tuscaloosa," but "Nick Saban will make that this year." Accordingly, he supports a system where "the football and men's basketball players get paid," while "lacrosse, field hockey, softball, baseball, soccer players get nothing." In fact, a particularly convincing aspect of Wilbon's argument is his rebuttal for those who were not in favor of paying athletes because of the inability to do so "fairly":

Using the inability to distribute the funds equally as an impediment is an excuse, a rather intellectually lazy one at that. Nothing about the way hundreds of millions of dollars is distributed is equitable or even fair. . . . Of the $\$ 174$ million distributed from five bowl games, 83.4 percent went to six conferences in 2011. . . . So, the equitable-application excuse for not paying 
athletes doesn't hold water; at the very least there's a level of hypocrisy here that ought to make the opponents of paying athletes uncomfortable.

(Wilbon, 2011)

To further illustrate his point, not only does Wilbon refute the claims of unfairness, but he also continues on to reframe the University of Georgia "scandal" in which the wide receiver on the football team sold his jersey for $\$ 1,000$ :

If somebody is willing to give A. J. Green $\$ 750$ or $\$ 1,000$ or even $\$ 2,500$ for his Georgia Bulldogs jersey, fine, good. If one of his teammates, a tackle, can fetch only $\$ 50$ for his jersey, then it'll be a good marketing lesson for both of them. It's called supply and demand, and if both men are fortunate enough to reach the NFL it'll be a lesson worth learning because that dynamic will exist their entire careers. If a soccer player can't get a dime for his jersey, well, there's a realization in that, too.

(Wilbon, 2011)

Here, Wilbon (2011), like Sack, alludes to the added value of engaging in a free market for student-athletes beyond their getting paid to play. As Ben Glicksman (2012) posits in Game Change: Letting Student-Athletes Earn a Living, allowing studentathletes to endorse products and use their fame to earn money would "teach them valuable lessons about economics" and "help keep players in school," by encouraging "more students to complete their degrees instead of leaving early to play professionally." Thus, he concludes, "if the NCAA truly puts the student first in student-athlete, then a change must be made to help keep players in school" (Glicksman, 2012, p. 13). Unfortunately, no such change was made.

The end of the OSU scandal makes an interesting case for why things remain as is. Though the NCAA alleges that the five OSU football players who violated the amateurism rules were allowed to postpone their suspension and play in the Sugar Bowl because they "did not receive adequate rules education during the time period the violations occurred" (NCAA, 2010), few believe these claims. Take, for instance, the response of Bob Hunter, a writer for the Columbus Dispatch:

No columnist or commentator I've found can see the logic in the NCAA ruling permitting the Ohio State players to play in New Orleans and then sit out five games next season. The message that both instances send is that rules are interpreted differently when it means protecting TV and bowl partners that have become so lucrative for its member schools.

(Hunter, 2011)

It would seem that the NCAA's stance around amateurism is hypocritical: while they continue to impose these outdated and exploitative rules on their studentathletes, they themselves are unwilling to prioritize these rules when ratings and profits are at stake. To be clear, the argument here is not whether profit should be 
the end goal, but rather for transparency around the revenue distribution model. If profit is indeed the end goal, then those creating the profits undoubtedly deserve to see, at minimum, a "teeny, tiny slice of it."

\section{References}

Bakalar, N. (2009, January 3). In BCS, dollars are the only relevant numbers. Retrieved from http://nyti.ms/2cNeJtm

Berkowitz, S., \& Upton, J. (2011a, March 30). An analysis of salaries for college basketball coaches. Retrieved from http://usatoday30.usatoday.com/sports/college/mensbasketball/ 2011-coaches-salary-database.htm

Berkowitz, S., \& Upton, J. (2011b, June 16). Money flows to college sports: Spending up amid schools' tight times. Retrieved from www.pressreader.com/usa/usa-today-interna tional-edition/20110617/textview

Branch, T. (2011). The shame of college sports. The Atlantic, 308(3), 80-110.

Byers, W., \& Hammer, C. (1997). Unsportsmanlike conduct: Exploiting college athletes. Ann Arbor: University of Michigan Press.

Clotfelter, C. T. (2011). Big-time sports in American universities. New York: Cambridge University Press.

Glicksman, B. (2012). Game change: Letting student-athletes earn a living. Sports $\mathcal{E}$ Entertainment Law Journal, 2(1), 1-25.

Greenberg, M. J., \& Smith, J. S. (2007). A study of Division I assistant football and men's basketball coaches' contracts. Marquette Sports Law Review, 18(1), 25-99.

Huma, R., \& Staurowsky, E. J. (2011). The price of poverty in big time college sport. Riverside, CA: National College Players Association.

Hunter, B. (2011, January 9). Delaying players' suspensions still seems dicey. Retrieved from www.dispatch.com/content/stories/sports/2011/01/09/delaying-players-suspensionsstill-seems-dicey.html

McCormick, A., \& McCormick, R. (2012). Race and interest convergence in NCAA sports. Wake Forest Journal of Law \& Policy, 2(1), 17-43.

McCormick, R., \& McCormick, A. (2010). Major college sports: A modern apartheid. Texas Review of Entertainment \& Sports Law, 12(1), 12-51.

National Collegiate Athletic Association. (2010). NCAA requires loss of contests for six Ohio State football student-athletes. Retrieved from www.ncaa.org

National Collegiate Athletic Association. (2011a). 2012 NCAA Division I Manual: Constitution, operating bylaws, administrative bylaws. Indianapolis, IN: Author.

National Collegiate Athletic Association. (2011b). The Ohio State University Public Infractions Report. Retrieved from www.ncaa.org

Ohio State Athletics. (2012). The Ohio State University annual report concerning compliance and education program (Case No. M352). Columbus, OH: The Ohio State University.

O'Neil, D. (2011, October 25). Student-athletes ask: Will NCAA listen. Retrieved from www.espn.com/college-sports/story/_/id/7148175/ncaa-student-athletes-ask-cuttelevision-revenue-cover-school-costs

Oriard, M. (2009). Bowled over: Big-time college football from the sixties to the BCS. Chapel Hill: University of North Carolina Press.

Rhoden, W. C. (2007). Forty million dollar slaves: The rise, fall, and redemption of the black athlete. New York: Three Rivers Press.

Robinson, C., \& Wetzel, D. (2011). Tressel knew of gear scheme last April. Retrieved from www.rivals.yahoo.com/ncaa/football/news 
58 Jamel K. Donnor and Collin D. Williams Jr.

Sack, A. (2009, March 18). March money madness. Retrieved from http://roomfordebate. blogs.nytimes.com/2009/03/18/march-money-madness

Sandomir, R., \& Thamel, P. (2010, April 22). TV deal pushes NCAA closer to 68-team tournament. Retrieved from http://nyti.ms/2cNfuCy

State Compensation Insurance Fund v. Industrial Commission, 314 P.2d 288, 135 Colo. 570(1957).

Thamel, P. (2011, September 9). With big paydays at stake, college teams scramble for a spot. Retrieved from http://nyti.ms/2cNffHQ

Tressel, J. (2011). Letter of resignation. Retrieved from http://media.cleveland.com/osu_ impact/other/Tressel-resignation-letter.pdf

Upton, J., Gillum, J., \& Berkowitz, S. (2010, April 12). Rising salaries of coaches force colleges to seek budget patch. Retrieved from http://usatoday30.usatoday.com/sports/college/ mensbasketball/2010-04-01-coaches-salaries-cover_N.htm

U.S. Department of Justice. (2010). Letter to The Ohio State University Office of Legal Affairs. Retrieved from http://media.cleveland.com/osu_impact/other/OhioStateDOJletter.pdf

Wilbon, M. (2011). College athletes deserve to be paid. Retrieved from www.espn.com

Wilson, M. J., Schrager, M., Burke, K. L., Hawkins, B. J., \& Gauntt, L. (2011). NCAA Division I men's basketball coaching contracts: A comparative analysis of incentives for athletic and academic team performance. Journal of Issues in Intercollegiate Athletics, 4(1), 396-410. 